\title{
MOZGÁSSÉRÜLT ELÍTÉLTEK HELYZETE A BÜNTETÉS-VÉGREHAJTÁSI INTÉZMÉNYEKBEN MAGYARORSZÁGON
}

\author{
Szerzők: \\ Ladányi Lili \\ Eszterházy Károly Egyetem (Magyarország)
}

\author{
Lektorok: \\ Magyar Adél Márta (Ph.D) \\ Szegedi Tudományegyetem \\ (Magyarország) \\ Czédli-Deák Andrea (Jur.) \\ Szegedi Járásbíróság büntető bírája
}

Első szerző e-mail címe:

ladanyi.lili@jgypk.szte.hu

Ladányi Lili (2020): Mozgássérült elítéltek helyzete a büntetés-végrehajtási intézményekben Magyarországon. Különleges Bánásmód, 6. (4). 63-71. DOI 10.18458/KB.2020.4.63

\begin{abstract}
Absztrakt
A tanulmány a magyarországi büntetés-végrehajtási intézményekben élő mozgássérült elítéltek helyzetére keresi a választ. A dolgozat célja a vonatkozó jogszabályok és a fogvatartási körülmények feltárásán túl egy etikai kérdéseket is érintő eset bemutatása. Az utóbbi években egyre nagyobb igény mutatkozik arra, hogy a büntetés-végrehajtás a mozgáskorlátozott fogvatartottak számára is alakítson ki megfelelő, kulturált, speciális helyzetükhöz igazodó elhelyezési körülményeket. Ez abból a jogelméleti alapvetésből következik, hogy a büntetés a szabadság elvonását jelenti, és annál nem többet. Tehát a mozgáskorlátozottság önmagában, nem jelenthet többletbüntetést a végrehajtás során. A bemutatott mozgáskorlátozott elítélt esete is ezt az alapvetést támasztja alá.
\end{abstract}

Kulcsszavak: mozgássérült, elítélt, büntetés-végrehajtási intézmény, akadálymentesítés

Diszciplina: fogyatékosságtudomány, jogtudomány

\section{Abstract \\ SITUATION OF CONVICTED PRISONERS \\ WITH PHYSICAL DIS ABILITY IN PENALTY INSTITUTIONS IN HUNGARY}

The study seeks to answer the situation of convicts with physical disabilities living in penitentiary institutions in Hungary. The aim of the dissertation is to present a case of ethical issues in addition to the exploration of the relevant legislation and environmental conditions. Recently there has been a growing need for prison staff to provide appropriate, cultured, special accommodation conditions for prisoners with 
physical disability showing that punishment is only deprivation of liberty and nothing more. Disability in itself should not be an additional punishment during the enforcement of verdicts. The case of the convicted person with physical disability presented also supports this statement.

Keywords: physical disability, convict, penitentiary institution, accessibility

Disciplines: disability studies, jurisprudence

A fogyatékosság individuális megközelítésével szemben egyre inkább teret nyerő szociális megközelítés jelentős mértékben elmozdul a fogyatékosság korábbi, személyorientált értelmezésétől. Ez a megközelítés a társadalom felelôsségének hangsúlyozása mellett a fogyatékos személyek csoportját sajátos emberi jogokkal (alapjogokkal) rendelkező csoportként kezeli, amely közösség és annak tagjai a diszkrimináció tilalmán túl egyes, kifejezetten az élethelyzetükhöz kapcsolódó külön jogok címzettjei (Zászkaliczky, 2003). A külön jogok nem csak a hétköznapi életben illetik meg embertársainkat, hanem abban az esetben is, ha a fogyatékos személy a jogtalanság talajára lép, és a tett súlya miatt fogvatartottként kerül kapcsolatba a az igazságszolgáltatás szereplőivel (Tóth, 2012). Jelen tanulmányban az ide vonatkozó hatályos jogszabályok ismertetése után a fogyatékos, azon belül is a mozgássérült személyek helyzetének vizsgálatára kerül sor a magyarországi büntetésvégrehajtási (bv.) intézményekben. Majd ismertetésre kerül egy mozgássérült elítélt esete a bűncselekmény elkövetésétôl a jelen helyzetéig, s végül felszínre kerülnek a lehetséges megoldások is a büntetés-végrehajtási intézményekben zajló diszkrimináció visszaszorítására.

\section{Vonatkozó jogszabályok}

Magyarország jogrendszerében a számos ide vonatkozó jogszabályból jelen tanulmányban azok kerülnek kiválogatásra, melyek a téma szempont- jából a legfontosabbak. Górcső alá kerül a minden magyar állampolgárra vonatkozó, alapvetó jogokat tartalmazó Magyarország Alaptörvénye, a 2007. évi XCII. törvény a Fogyatékossággal élő személyek jogairól szóló egyezmény és az ahhoz kapcsolódó Fakultatív Jegyzőkönyv kihirdetéséről, az 1998. évi XXVI. törvény a fogyatékos személyek jogairól és esélyegyenlőségük biztosításáról (Esélyegyenlőségi törvény), a 2012. évi C. törvény a Büntető Törvénykönyvről, valamint a 2013. évi CCXL. törvény a büntetések, az intézkedések, egyes kényszerintézkedések és a szabálysértési elzárás végrehajtásáról.

\section{Alaptörvény}

Magyarország Alaptörvénye I. cikkének 1 . bekezdése így szól: „AZ EMBER sérthetetlen és elidegeníthetetlen alapvető jogait tiszteletben kell tartani." A szabadságjogok az alapvető jogok közé tartoznak. Az elítéltek esetében, akik büntetésének lényege, hogy szabadságvesztésüket töltik, ezen szabadságjogok a törvényben meghatározottak szerint korlátozhatók. A korlátozás feltétele, hogy arányos, szükséges, és célszerű legyen, és jogszabály írja elő. Ennek megítéléséhez abból kell kiindulni, hogy az emberi méltósághoz és az egészséghez való jogok minden emberrel vele született, elidegeníthetetlen alapjogok. Ez azt jelenti, hogy senkit sem lehet kínzásnak, kegyetlen, megalázó, embertelen bánásmódnak alávetni, joga van a saját egészségének biztosításához. 
Az Alaptörvény II. és XX. cikkében ezek az elvárások így hangzanak: „Az emberi méltóság sérthetetlen. Minden embernek joga van az élethez és az emberi méltósághoz.” „Mindenkinek joga van a testi és lelki egészséghez." Ezen megállapítások fontos szerepet kapnak majd az esetleírás során, hiszen az esetben tárgyalt mozgássérült személy éppen emberi méltóságának megsértésére hivatkozva nyert pert a magyar állammal szemben.

2007. évi XCII. törvény a Fogyatékossággal élo" személyek jogairól szóló egyezmény és az abhoz kapcsolódó Fakultativ Jegyzökönyv kibirdetéséról

A jelen Egyezményből mindenképpen szükséges kiemelni az alábbi kulcsszavakat, amelyek a fogyatékos személyek csoportján belül az elítélt fogyatékos személyek esetében is alkalmazandó elvek kellene, hogy legyenek: ésszerû alkalmazkodás, hozzáférhetőség, illetve az embertelen vagy megalázó bánásmód tilalma.

$\mathrm{Az}$ ésszerű alkalmazkodás (2. cikk) amely az olyan „elengedhetetlen és megfelelő módosításokat és változtatásokat jelenti, amelyek nem jelentenek aránytalan és indokolatlan terhet, és adott esetben szükségesek, hogy biztosítsák a fogyatékossággal élő személy alapvető emberi jogainak és szabadságainak a mindenkit megillető, egyenlő mértékű élvezetét és gyakorlását".

A Hozzáférhetőség (9. cikk) jelen esetben a rendőrségen, a fogdán, a bíróságon és a büntetésvégrehajtási intézményekben a fizikai környezethez, illetve a büntetés-végrehajtási intézményen belül rendelkezésre álló lehetőségekhez (mosdó, WC, udvar, ebédlő) és szolgáltatásokhoz (könyvtár, munka, stb.) való hozzáférést jelenti. A 15. cikk kimondja, hogy „kínzás és más kegyetlen, embertelen vagy megalázó bánásmód vagy büntetés alkalmazása mindenkivel szemben tilos."

Esélyegyenlöségi törvény (1998. évi XXVI. törvény a fogyatékes személyek jogairól és esélyegyenlöségüle biztositásáról)
Magyarországon 1998 óta létezik a fogyatékos emberek társadalmi beilleszkedésének kereteit meghatározó Esélyegyenlőségi Törvény, melynek 5. § (1) pontja kimondja, hogy „a fogyatékos személynek joga van a számára akadálymentes, továbbá érzékelhető és biztonságos épített környezetre."

Ebben az évben megszületett az Országos Fogyatékosügyi Program is, amely preambulumában pontosan azokat az irányelveket fogalmazza meg, amelyek a jövő ellátórendszere felé kell, hogy mutassanak. A normalizáció alapelve azt rögzíti, hogy a fogyatékos emberek életkörülményeit, életstandardjait, lakókörülményeit a lehetô legközelebb kell hozni azokhoz az életmintákhoz és életfeltételekhez, melyeket a társadalom tagjai a maguk számára elfogadhatónak tekintenek. A tanulmányhoz kapcsolódóan mozgássérült elítélt celláját kellene olyan környezetté alakítani, ami a különleges körülmények keretein belül elfogadhatónak tekinthető. Az egyenlő bánásmód azt jelenti, hogy mindenkivel azonos méltóságú személyként kell bánni, aminek megvalósításához szükség lehet speciális bánásmódra. (Magyar Helsinki Bizottság, 2014). A pozitív diszkrimináció alapelvének értelmében adott esetben az esélyegyenlőség biztosítása pozitív megkülönböztetést tesz szükségessé, amely a bv. intézet falain beül is érvényes. Ezeknek az alapelveknek a megvalósulásától a szabadon éló társadalom keretein belül is még nagyon messze vagyunk, nemhogy a fogvatartottak környezetében, egy olyan ellátórendszerben, amely a közvéleményben ilyen negatív szerepet tölt be.

\section{2. évi C. törvény a Büntetó Törvénykönyvröl}

Ez a törvény a fogyatékosságot mint fogalmat kizárólag az áldozat szempontjából értelmezi.

Az elkövetô szempontjából kóros elmeállapotról mint büntetőséget kizáró okról beszél: 17. § (1) „Nem büntethető, aki a büntetendő cselekményt az elmemúködés olyan kóros állapotában követi el, amely képtelenné teszi cselekménye követ- 
kezményeinek a felismerésére, vagy arra, hogy e felismerésnek megfelelően cselekedjen.” A 78. § (1) bekezdése rendelkezik arról a speciális esetről, amikor a bíróság a nem büntethető elkövetővel szemben intézkedésként (és nem büntetésként) kényszergyógykezelést alkalmaz: „Személy elleni erőszakos vagy közveszélyt okozó büntetendő cselekmény elkövetőjének kényszergyógykezelését kell elrendelni, ha elmemúködésének kóros állapota miatt nem büntethetô, és tartani kell attól, hogy hasonló cselekményt fog elkövetni, feltéve, hogy büntethetősége esetén egyévi szabadságvesztésnél súlyosabb büntetést kellene kiszabni."

Tehát a fogyatékosság léte adott esetben nem zárja ki, hogy a bűntény elkövetójével szemben szankció kerüljön alkalmazásra. A kóros elmeállapot bűncselekmény pillanatában fennálló tényét csak egy igazságügyi elmeorvos-szakértő és egy igazságügyi orvosszakértő együttesen állapíthatja meg. Fogyatékosságok esetében kóros elmeállapotnak számíthatnak az értelmi fogyatékosság, illetve az autizmus egyes esetei is, de önmagában pl. a mozgásfogyatékosság nem.

2013. évi CCXL. törvény a büntetések, az intézkedések, egyes kényszerintézkedések és a szabálysértési elzárás végrebajtásáról

A címben szereplő törvény ,az ember sérthetetlen és elidegeníthetetlen alapvető jogainak védelme, kiemelten az elítéltek és az egyéb jogcímen fogvatartottak emberi méltóságának a tiszteletben tartása érdekében, a kínzás, kegyetlen, embertelen vagy megalázó bánásmód tilalmának és az egyenlő bánásmód követelményének érvényesülése céljából" jött létre. Minden olyan helyzetben, amikor intézményesítetten fosztanak meg embereket a személyi szabadságuktól, megjelenik annak veszélye, hogy a büntetőhatalmat megjelenítő „őrzők” megsérthetik az „őrzöttek” alapvető jogait. (Pajcsicsné, 2013)

A 10. § alapján az elítélt az ôt ért jogsérelmekkel kapcsolatban fordulhat az elzárás és a szabálysértési elzárás végrehajtásának törvényességi felügyeletét ellátó ügyészhez, az alapvető jogok biztosához, a kínzás és más kegyetlen, embertelen vagy megalázó bánásmód vagy büntetés elleni fakultatív jegyzőkönyv 3. cikke szerint nemzeti megelőző mechanizmus feladatainak teljesítésére felhatalmazott munkatársához, illetve az elismerten erre hatáskörrel rendelkező nemzetközi jogvédő szervezethez.

\section{Mozgáskorlátozott fogvatartottak helyzete Magyarországon}

$\mathrm{Az}$ utóbbi években egyre nagyobb igény mutatkozik arra, hogy a büntetés-végrehajtás a mozgáskorlátozott fogvatartottak számára is alakítson ki megfelelő, kulturált, speciális helyzetükhöz igazodó elhelyezési körülményeket. Ez abból a jogelméleti alapvetésből következik, hogy a büntetés a szabadság elvonását jelenti, és annál nem többet. Tehát a mozgáskorlátozottság önmagában nem jelenthet többletbüntetést a végrehajtás során. Az épített környezetet illetően az 1. táblázatban levő intézményekben biztosítanak a fogyatékos személyek jogairól és esélyegyenlőségük biztosításáról szóló 1998. évi XXVI. törvényben rögzített módon akadálymentes elhelyezési lehetőséget.

\section{1. táblázat: A büntetés végrehajtási helyeken rendel-} kezésre álló féróhelyek száma a fogyatékos fogvatartottake számára. Forrás: Veszeli, 2012.

\begin{tabular}{|l|r|}
\hline Büntetés-végrehajtási (Bv.) Intézet & \multicolumn{1}{|c|}{$\begin{array}{c}\text { Férőhelyek } \\
\text { száma }\end{array}$} \\
\hline Sopronkóhidai Fegyház és Börtön & 8 \\
\hline Veszprém Megyei Bv. Intézet & 2 \\
\hline Tiszalöki Országos Bv. Intézet & 20 \\
\hline Szombathelyi Országos Bv. Intézet & 14 \\
\hline Pálhalmai Országos Bv. Intézet & 80 \\
\hline $\begin{array}{l}\text { Szegedi Fegyház és Börtön } \\
\text { (Nagyfai Krónikus Utókezelő) }\end{array}$ & 133 \\
\hline Összesen & \\
\hline
\end{tabular}


A Börtönügyi Szemle 2012-ben az alábbi fotókkal mutatta be egyes, a mozgáskorlátozott elítéltek számára kialakított zárkák részleteit (1. képsorozat).

1.képsorozat. A mozgáskorlátozottak számára kialakitott zárkák részletei. Forrás: Veszeli, 2012, 65 66.

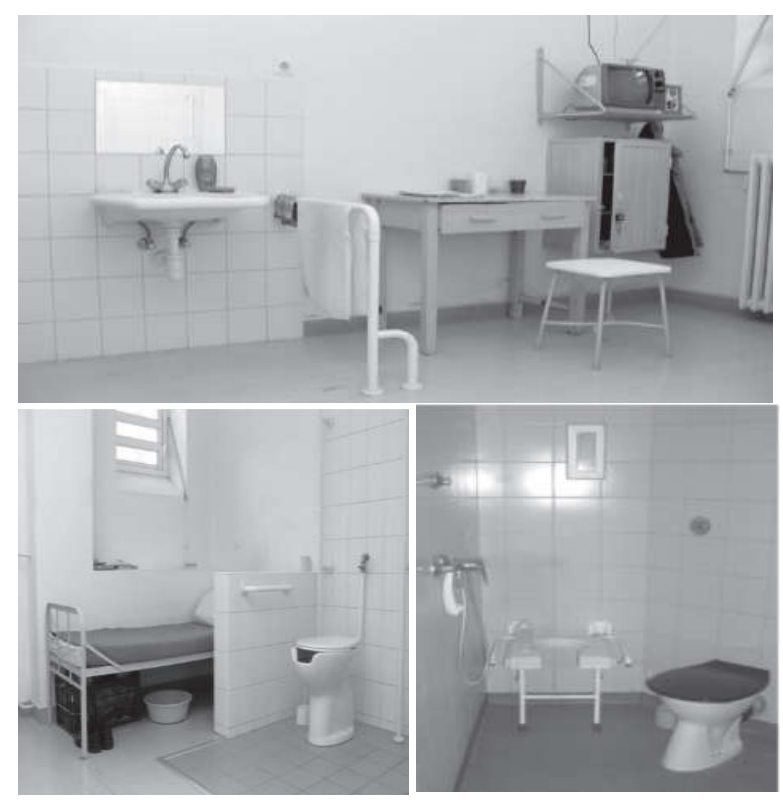

A segédeszköz (könyök- vagy hónaljmankó, járóbot, járókeret, ülőkocsi, sztómazsák, inkontinencia-betét/pelenka, állandó vizeletkatéter, alvási apnoe készülék, oxigénpalack stb.) használatát a büntetés-végrehajtási intézménynek kell biztosítania az arra szoruló elítélt számára, ám e személyek elhelyezése szinte mindig nehézséget okoz, mivel a túlzsúfoltság miatt magányos elhelyezésre nagyon csekély lehetőség adott, és a segédeszközök miatti komfortcsökkenést a normál zárkaközösségek nehezen tolerálják. Az amúgy is szúkös zárkában, lakóhelyiségben a segédeszköz helyet foglal, ugyanakkor támadásra, rendkívüli esemény okozására lehet alkalmas, továbbá folyam- atos múködése/hordása zajos, vagy kellemetlen szagokkal jár (Veszeli, 2012).

$\mathrm{Az}$ alapvető jogok biztosához (korábban: az állampolgári jogok országgyúlési biztosa) az Esélyegyenlőségi törvény hatályba lépése óta csupán néhány panaszos megkeresés érkezett mozgáskorlátozott fogvatartottaktól. Az állampolgári jogok országgyúlési biztosának Jelentése az AJB-1161/2009. számú ügyben alapján a Sopronkőhidai Fegyház és Börtönben fogva tartott, mozgáskorlátozott panaszos, aki dolgozatom esetbemutatásának alanya is egyben, a bv. intézetekben való elhelyezésének, ellátásának a körülményeit, valamint a tárgyalásokra való szállításának a módját sérelmezte. Egy másik mozgáskorlátozott panaszos azt sérelmezte, hogy a rendőrségi fogdára való elóállitását követően a földön, egy szivacson kellett aludnia, a WC-t pedig nem tudta használni, mert nem volt kapaszkodó. Az Igazságügyi Megfigyelő és Elmegyógyító Intézetből (IMEI) is érkeztek panaszok a kapcsolattartás, illetve bizonyos termékek (cigaretta, kávé, tea) fogyasztásának a korlátozása miatt.

Nem lehet figyelmen kívül hagyni az alapvető jogok biztosa tevékenységének jelentőségét, aki abban az esetben, ha jogsérelmet is állapít meg, akkor sem kötelezheti a büntetés-végrehajtási intézetet a jogsértő helyzet megszüntetésére, vagy a jogsértés egyéb módon való orvosolására, csupán javaslatot tehet. Az elítélt ilyen jellegú panaszaival az ügyészséghez is fordulhat, ám ebben az esetben a legáltalánosabb problémát az jelenti, hogy mivel ugyanahhoz a szervezethez tartozik, amely a fogvatartottal szemben a vádat képviselte, ezáltal jelentôs szerepe volt abban, hogy az elítélt a bv. intézménybe kerüljön, a fogvatartottak bizalmatlanok velük szemben (Kádár, 2010). Jogorvoslat szempontjából nagy jelentősége lehet a jogi szakértelemmel rendelkező civil szervezeteknek (Magyar Helsinki Bizottság), amelyet nagyon jól szemléltet E. Zoltán esete. (Kádár, 2010) 


\section{Az E. Zoltán ügy}

E. Zoltán 1962-ben született, és Szegeden élt. A többszörösen büntetett előéletű férfit 2003. május 13-án hajnalban egy fővárosi villa fegyveres kirablása közben tetten érték. E. Zoltán előbb megadást színlelt, majd a nála lévő hangtompítós pisztolyával hirtelen lôni kezdett, egy rendőrt megölt, egy másikat pedig megsebesített. A tűzharcban E. Zoltán maga is gerincsérülést szenvedett, amelynek következtében deréktól lefelé mindkét lába megbénult. Bénulás következtében egészségkárosodása jelenleg is 100\%-os, csak kerekesszékben képes közlekedni. Inkontinencia is fellépett nála, pelen-kát kell használnia (Strasbourg, 2010).

Büntetőügyében 2005. április 27-én született jogerős ítélet, a bíróság életfogytig tartó, letöltendő szabadságvesztésre ítélte E. Zoltánt. Ez azt jelenti, hogy az elítélt leghamarabb harminchárom év múlva szabadulhat. E. Zoltán a Szegedi Fegyház és Börtönben kezdte meg büntetését, ún. IV-es biztonsági fokozatú rabként, ami a legszigorúbb ôrzési kategóriának tekinthető, kizárólag a legveszélyesebbnek tartott elítélteknél alkalmazzák (Legát, 2006).

Az elítéltet 2005. február 25. és 2006. december 15. között a Szegedi Fegyház és Börtönben tartották fogva, ahol kimondottan miatta végeztek átalakításokat (például rámpát építettek). Azonban, mivel a börtönszabályzat éppúgy vonatkozik rá is, mint az egészséges elítéltekre, E. Zoltán számos kötelezettségnek (beágyazás, takarítás, reggeli átvétele stb.) képtelen volt eleget tenni. (Legát, 2006) Bevetett ágyon ruhástól kellett aludnia, s kabátját kellett takarónak használnia annak érdekében, hogy elkerülje a meghatározott időre történő beágyazást előíró zárkarend megsértése miatti szankciót. Mivel a személyzettől nem kapott segítséget, csak akkor tudott mosakodni vagy szükségét elvégezni, hogyha szobatársai segítettek neki. Nem biztosítottak számára megfelelô fürdôszéket; fürdőszék helyett fából készült WC ülőkét kapott, ami - fürdésre alkalmatlan lévén - gyorsan elrothadt, és egy alka- lommal össze is törött alatta. Mivel fogyatékossága és inkontinenciája miatt a többi elítélt zaklatta, nem vett részt a napi szabad levegón tartózkodáson (Strasbourg, 2010).

E. Zoltán 2006-ban így nyilatkozott: „Álláspontom szerint a velem szembeni bánásmód megalázó, embertelen, diszkriminatív. Kiszolgáltatottnak érzem magam, pedig ellenőrzött körülmények között jogkövető vagyok. Kerülöm a konfliktusokat, de meggyőződésem, hogy ennél rosszabb már nem lehetne a helyzetem. Megkerestem a börtönpszichológust, sôt még a rabbit is. A rabbi úr együttérzésérôl biztosított, mást nem tehet értem, a pszichológus annyit mondott, túzzek ki magam elé rövid távú célokat, amiket el tudok érni, és azzal foglaljam le magam" (Legát, 2006).

E. Zoltán a fent leírtak miatt a Csongrád Megyei Fógugyészséghez nyújtott be panaszt, de annak nem lett eredménye. A börtön egészségügyi szolgálata szerint a kérelmező, többek között, magas vérnyomásban, paraplégiában, neurogén hólyag betegségben és túlsúlyban szenvedett. Speciális büntetés-végrehajtási intézetbe történő átszállítására javaslat született, amelyet azonban a börtön vezetősége nem fogadott el (Strasbourg, 2010).

E. Zoltánt az úgynevezett IV-es, legveszélyesebb biztonsági csoportba sorolták, ami azért jelentett problémát, mert az ellene még folyamatban levő további büntetőeljárások miatt a Fôvárosi Büntetés-végrehajtási Intézetbe kellett rendszeresen átszállítani. Az átszállítások alkalmával pedig a biztonsági besorolására való tekintettel, övbilinccsel megbilincselték. Az utazások teljes időtartalma alatt a fejével volt kénytelen kitámasztani magát, mivel a lábai bénultak, a kezei pedig a derekához voltak bilincselve. Mivel ebben a testhelyzetben nem mindig tudta megakadályozni, hogy a fordulások alkalmával leessen a földre, előfordult, hogy az út hátralévő részében a szállítójármű padlóján hánykolódott. Mivel önállóan nem tudott beszállni és kiszállni a rabszállító jármúbe, a szállítást végző felügyelők vagy rabtársai rángatták, vonszolták az 
övbilincsénél fogva be, illetve ki az egyszemélyes fülkéből. Szállitásai során többször előfordult, hogy orvosilag dokumentált sérüléseket szenvedett el (Kádár, 2010).

Egy 2009. június 23-án történt átszállítást követően E. Zoltán az állampolgári jogok országgyúlési biztosához fordult panaszával. Az esettel kapcsolatos AJB-6462/2010. számú jelentés alapján az elítéltet a Pest Megyei Bíróságra június 23-án reggel egy 38 fôs szállitójármúben akarták szállítani, hogy a tárgyaláson megjelenhessen. A fogvatartott jelezte, hogy ez a szállítójármú nem biztonságos számára, mivel nincs felszerelve biztonsági övvel, de az illetékesek ezt figyelmen kívül hagyták.

E. Zoltán utolsó lehetôségként félmeztelenre vetkőzött (levette az ingét) és nem hajtotta a kerekesszékét. Saját elmondása alapján ezután bevonszolták a jármúbe, és a sáros fémpadlón, félmeztelenül szállították, Állítása szerint kétszer leejtették, mert az esôtől vizes lett a felsőteste, majd a fémpadlóra fektették, de a kinyúitott lábai nem fértek be a fakkba, ezért az ajtót rányomták a lábaira, és így „magzatpózban” szállították a kijelölt helyre.

A fogvatartott panasza nyomán, az országos parancsnok utasítására az intézetparancsnok helyettese megvizsgálta az esetet. Jelentése szerint E. Zoltánt a szállítójármű egyszemélyes fakkjában ülő helyzetben helyezték el úgy, hogy „testtartása a szállítás közben stabil maradjon”, illetve a levetett felsőruházatát is a testére tették. A fogvatartott állítását, miszerint félmeztelenül, „magzatpózban” szállították, - a beérkezett jelentések alapján - nem tartotta igazolhatónak. E. Zoltánnal szemben tanúsított passzív ellenállás miatt fegyelmi lapot állítottak ki. Első fokon június 26-án, másodfokon június 29-én háromhavi 50\%-os kiétkezés-csökkentéssel sújtották.

A történtek után az elítélt panaszaival eljutott a Magyar Helsinki Bizottsághoz, amely szervezet 2006 szeptemberében kérelmet nyújtott be az Em- beri Jogok Európai Bíróságához E. Zoltán képviseletében. Vagy e történések hatására, vagy ezektől függetlenül E. Zoltánt 2006. december 15én Szegedről áthelyezték Sopronkőhidára, ahol két, speciálisan a mozgáskorlátozott fogvatartottak számára kialakított zárka található. Megjegyzem, a két zárka ekkor már 10 hónapja üresen állt (Kádár, 2010).

2006. december 18-án E. Zoltánt igazságügyi orvosszakértô vizsgálta meg. Véleményében a szakértô kifejtette: „.... [A felállás tekintetében] a fogvatartott részben vagy egészben túlozza fájdalmát... A fogvatartott 100\%-os rokkant ..., ugyanakkor nem teljesen képtelen az önellátásra. Folyamatos evési ingere, valamint az az álláspontja, hogy fájdalom esetén sem szed fájdalomcsillapítót... komoly pszichés akadályát képezi fokozottabb mobilizálhatóságának. Ugyanakkor, ... önmaga a fájdalom sem bizonyítható kétséget kizárólag. Igazságügyi orvosszakértői szempontból megállapítható, hogy... a fogvatartott valamennyi olyan orvosi, ápolói, gondozói segítséget megkapott, amelyre szüksége volt.”' (Strasbourg, 2010)

Ezen fejlemények ellenére Az Emberi Jogok Európai Bírósága megállapította, „hogy a Szegedi Fegyház és Börtönben történt fogvatartása alatt a kérelmezőt megalázó bánásmódnak vetették alá. Bár a Kormány dicséretre méltó erőfeszítéseket tett a kérelmező helyzetének javítására azzal, hogy 2006. december 15-én a kérelmezőt egy speciálisan kialakított intézménybe szállították át, ezen erőfeszítésekre túl későn került sor ahhoz, hogy enyhítsék az Emberi Jogok Európai Egyezménye 3. cikkének megsértését", miszerint senkit sem lehet kínzásnak, vagy embertelen, megalázó bánásmódnak, vagy büntetésnek alávetni. A Bíróság a kérelmezőnek 12.000 Euró összegú nem vagyoni kártérítést ítélt meg (Strasbourg, 2010).

Legutóbb 2015-ben jelent meg egy újságcikk E. Zoltánról Fültisztító Pálcikát csomagol a milliomos rendőrgyilkos címmel a vs.hu internetes portálon. Egy fotót is közöltek róla és cellájáról (2.kép): 
2. kép. Az elitélt munka közben. Forrás: VS.bul Kummer és Munkácsi, 2015.

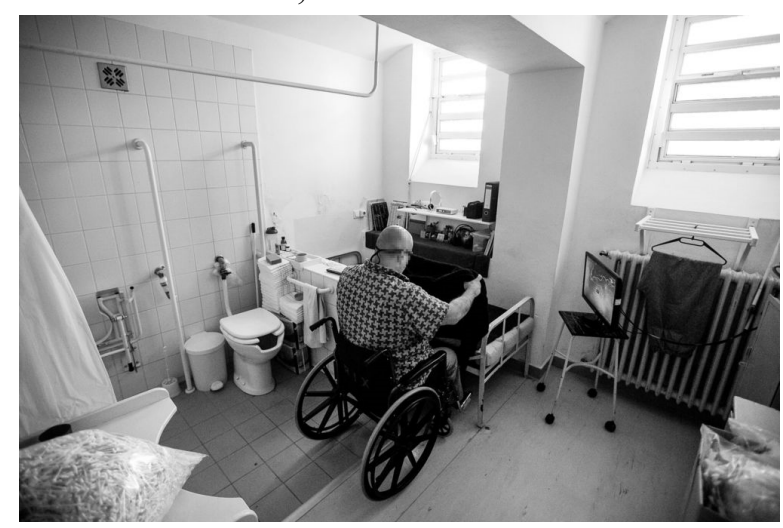

A cikkben leírják, hogy E. Zoltán a fotón látható zárkában tölti mindennapjait. Fültisztító pálcikák csomagolása a munkája, nem jár ki a sétaudvarra, mert nem szereti, ha más fogvatartottak bizalmaskodnak vele (Kummer és Munkácsy, 2015).

Lehetőségek a Büntetés-végrehajtási Intézetekben a diszkrimináció visszaszorítására

Az esetleírásból tükröződik, hogy az egyenlő bánásmód nem csak kötelező, de hasznos is. A nemzetközi jog és a magyar jogszabályok alapján a közfeladatot - így például a szabadságvesztés és elzárás végrehajtását - ellátó szervezetek valamennyi tevékenységük során kötelesek megtartani az egyenlő bánásmód követelményét. Ezt a kötelezettséget a büntetés-végrehajtási szervezet etikai kódexe is tartalmazza, miszerint a személyi állomány tagjainak tartózkodniuk kell mindennemú megkülönböztetéstől a munkájuk végrehajtása során, és minden rendelkezésre álló eszközzel meg kell akadályozniuk, hogy más személyek a diszkrimináció eszközével élhessenek (Magyar Helsinki Bizottság, 2004). Ennek ellenére a hátrányos megkülönböztetés mégis általános jelenség a büntetés-végrehajtási intézményekben.

A Magyar Helsinki Bizottság (2004) útmutatójában az alábbi, ENSZ ajánlásokat teszi a hátrányos megkülönböztetés visszaszorítása érdekében:

- A vezetés elköteleződése az egyenlő bánásmód mellett,

- specializált eljárásrendek, útmutatók és irányelvek kidolgozása és alkalmazása,

- az etikai kódex mellet egyes szám első személyben íródott magatartási kódex bevezetése a személyi állomány tagjai számára,

- a kisebbségi és sérülékeny (etnikai csoportok, nők, fogyatékossággal élők) csoportok tagjainak megjelenése a személyi állomány összetételében,

- képzések, érzékenyítő programok a fogvatartottak számára is,

- a diszkriminációs esetek eredményes feltárása és visszaszorítása érdekében független, hatékony, korrekt, egyszerúen igénybe vehető panaszmechanizmus múködtetése,

- jogsértés esetén alapos kivizsgálás pontos dokumentációval és felelősségre vonással.

- Folyamatos monitoring, adatgyújtés, kutatás az aktuális bv. intézetbeli helyzet felmérésére és/vagy az antidiszkriminációs lépések és eredmények értékelésére.

\section{Záró gondolatok}

Jelen tanulmány egy jelentősetikai problémát, a büntetésvégrehajtási intézményben élő mozgáskorlátozott elítélteket megilletô jogok érvényesülését feszegeti. A hatályos jogszabályok és a feltárt eset kapcsán kijelenthető, hogy az elkövetett bűncselekménytől függetlenül a fogyatékos személy számára mozgáskorlátozottsága nem jelenthet többletbüntetést a végrehajtás során. Az egyenlő bánásmód elvét követve a büntetés számára is kizárólag a szabadság elvonását kellene, hogy jelentse, és mozgáskorlátozottsága miatt nem részesülhetne méltánytalan és megalázó bánásmódban. 


\section{Irodalom}

Kádár A. K. (2010). A civil szervezetek szerepe a fogvatartási panaszjog érvényesítésében. In: Vig D. (szerk.). A globalizáció kibivásai - Kriminálpolitikai válaszok. Kriminológiai Közlemények 68. 59-65.

Kummer J. \& Munkácsy M. (2015). Fültisztitió pálcikát csomagol a milliomos rendốrgyilkos. Web: https://vs.hu/kozelet/osszes/fultisztitopalcikat-csomagol-a-milliomos-rendorgyilkos11018) Letöltés: 2020.12.10.

Legát T. (2006). Egy különösen veszélyes elitélt: Nem történt szabálytalanság. Budapest, Hungary: Magyar Narancs 2006/47. Web: http://m.magyar narancs.hu/belpol/egy kulonosen veszelyes el itelt nem tortent szabalytalansag-66305). Letöltés: 2020.12.10.

Magyar Helsinki Bizottság (2004). Egyenló esélyek. Útmutató a diszkriminációmentes bánásmód elösegitésébez a büntetés-végrehajtásban. Budapest, Hungary: Magyar Helsinki Bizottság. Web: https://helsinki.hu/wp-content/uploads/

MHB egyenlo esely antidiszk utmutato bv 2 014.pdf . Letöltés: 2020.12.10.

Pajcsicsné Csóré E. (szerk.). (2013). AJB Projektffiretete: „Emberi jogok kint és bent - ombudsmani szemmel" A büntetés-végrehajtás fogvatartottjainak, a külföldiek idegenrendészeti és menedékjogi fogva tartásának alapjogi összefüggéseit, valamint az ügyvédek és a hozzájuk fordulók jogait viæsgáló projekt 2013/2. Budapest, Hungary: Alapvető Jogok Biztosának Hivatala.Web: http://www.ajbh.hu/documents 110180/124834/buntetes vegrehajtas 2013.pdf L216e4991-f6d5-44ce-906c-db8f1d252e74. Letöltés: 2020.12.10.

Strasbourg (2010). Emberi Jogok Európai Bírósága Második Szelkció: Engel kontra Magyarország Ügy (46857/06. s₹. kérelem) ÍTÉLET Strasbourg 2010. május 20. Strasbourg, France: Emberi Jogok Európai Bírósága Második szekció. Web: https://helsinki.hu/wp-
ontent/uploads/Engel_v_Hungary HUN.pdf. Letöltés: 2020.12.10.

Tóth I. (2012). A fogyatékkal élő fogvatartottak fogdai befogadásának jogi aggályai. Börtönügyi Szemle, 31 (2). 53-62.

Veszeli D. (2012). A mozgáskorlátozott és fogyatékos fogvatartottak bv. intézeti elhelyezése. Börtönügyi szemle - 31 (2). 63-70.

Zászkaliczky P. (2003). Gyógypedagógiai alapmodellek. A fogyatékosság értelmezési lehetőségei. Embertárs 2003/3, 40-52.

\section{Hivatkozott jogszabályok}

Magyarország Alaptörvénye (2011. április 25.)

2007. évi XCII. törvény a Fogyatékossággal élő személyek jogairól szóló egyezmény és az ahhoz kapcsolódó Fakultatív Jegyzőkönyv kihirdetéséről

1998. évi XXVI. törvény a fogyatékos személyek jogairól és esélyegyenlőségük biztosításáról 2012. évi C. törvény a Büntető Törvénykönyvről 2013. évi CCXL. törvény a büntetések, az intézkedések, egyes kényszerintézkedések és a szabálysértési elzárás végrehajtásáról

\section{Hivatkozott jelentések}

Az állampolgári jogok országgyúlési biztosának Jelentése az AJB-1161/2009. számú ügyben Web: https://ww.ajbh.hu/documents/10180/104939 L200901161.rtf/67227029-05bc-42b7-b6f137f55b4063ce?version=1.0.Letöltés: 2020.12.10.

Az állampolgári jogok országgyúlési biztosának Jelentése az AJB-6462/2010. számú ügyben (Elŏzményi ügy: AJB-5337/2009). Web: https://www.ajbh.hu/documents/10180/1059 26/201006462.rtf/a67dcbdc-a0d1-496c-bbdc40bd152617fd;jsessionid $=8$ B0C 5 CCF65E87AB 33F59CCC95D2300B9?version=1.0. Letöltés: 2020.12.10. 